\title{
PENATAUSAHAAN BARANG MILIK DAERAH PADA DINAS PERUMAHAN KAWASAN PERMUKIMAN DAN PERTANAHAN KABUPATEN TORAJA UTARA
}

\section{ADMINISTRATION OF REGIONAL OWNED GOODS IN THE DEPARTMENT OF HOUSING IN THE RESIDENTIAL AND LAND AREA OF NORTH TORAJA DISTRICT}

\author{
Daniel Sari Patontongan ${ }^{1}$, Frida Chairunisa ${ }^{2}$, dan Nuraeni Sayuti ${ }^{3}$ \\ ${ }^{\mathbf{1}}$ Dinas Perumahan Kawasan Permukiman Dan Pertanahan Kabupaten Toraja Utara \\ e-mail: dpatontongan@yahoo.co.id \\ ${ }^{2}$ Politeknik Sekolah Tinggi Ilmu Administrasi-Lembaga Administrasi Negara, Makassar \\ e-mail: fchairunisa@yahoo.com \\ ${ }^{3}$ Politeknik Sekolah Tinggi Ilmu Administrasi-Lembaga Administrasi Negara, Makassar \\ e-mail: neno_stialan@yahoo.co.id
}

\begin{abstract}
ABSTRAK
Penatausahaan barang milik daerah pada Dinas Perumahan Kawasan Permukiman Dan Pertanahan Kabupaten Toraja Utara masih belum berjalan dengan baik, dimana aset yang berpindah-pindah ruangan sehingga tidak diketahui keberadaannya. Tujuan penelitian ini untuk mengetahui bagaimana Penatausahaan Barang Milik Daerah Pada Dinas Perumahan Kawasan Permukiman Dan Pertanahan Kabupaten Toraja Utara. Pendekatan penelitian yang digunakan yaitu pendekatan kualitatif. Adapun jumlah informan dalam penelitian ini sebanyak 10 orang. Hasil penelitian (1) Pembukuan masih menggunakan sistem manual, masih terdapat BMD yang tidak tercatat dengan baik dan seringnya pengurus barang terlambat dalam melakukan pembukuan; (2) Inventarisasi BMD belum semuanya memiliki label kode barang. Selain itu, tidak ada daftar rekap barang dan tidak ada kartu inventaris barang pada setiap ruangan; (3) Pelaporan yang dibuat oleh pengurus barang dalam melaporkan data BMD masih sering terlambat karena kurang disiplinnya pengurus barang dalam membuat laporan; dan (4) Sumber daya manusia pengurus barang masih kurang memadai sehingga menjadi salah satu kendala atau penyebab dari belum terlaksanannya penatausahaan dengan baik. Selain itu, pengurus barang tidak pernah mengikuti atau mendapatkan pelatihan terkait penatausahaan BMD. Oleh karena itu, perlu adanya kedisiplinan dari pengurus barang untuk melakukan pembukuan dengan cepat, membuat label dan kartu inventaris serta perlu adanya kegiatan pelatihan bagi pengurus barang terkait dengan penatausahaan BMD.
\end{abstract}

Kata Kunci: Penatausahan BMD, Pembukuan, Inventarisasi, Pelaporan.

\begin{abstract}
The administration of regional property at the Housing Area, Settlement and Land Service Office of North Toraja Regency is still not going well, where the assets are moving between rooms so that their whereabouts are not known. The purpose of this research is to find out how the Administration of Regional Property in the Housing and Land Service of North Toraja Regency. The research approach used is a qualitative approach. The number of informants in this study were 10 people. The results of the study (1) bookkeeping still uses a manual system, there are still BMDs that are not well recorded
\end{abstract}




\section{Daniel Sari Patontongan, Frida Chairunisa, dan Nuraeni Sayuti /Jurnal Administrasi Negara, V26 - 03 (2020)/304-326}

and the management of goods is often late in making bookkeeping; (2) Not all BMD inventories have item code labels. In addition, there is no item recap list and no inventory card for each room; (3) Reports made by the goods manager in reporting BMD data are often late due to lack of discipline in the management of goods in making reports; and (4) Human resources for the management of goods are still inadequate so that it becomes one of the obstacles or causes of not well-implemented administration. In addition, the goods manager has never attended or received training related to $B M D$ administration. Therefore, there needs to be discipline from the goods manager to do fast bookkeeping, make inventory labels and cards and there is a need for training activities for goods managers related to the administration of $B M D$.

Keywords : Management of BMD, Bookkeeping, Inventory, Reporting.

\section{PENDAHULUAN}

Peraturan Menteri Dalam Negeri Republik Indonesia Nomor 19 Tahun 2016 Tentang Pedoman Pengelolaan Barang Milik Daerah, bahwa Pengelolaan Barang Milik Daerah adalah keseluruhan kegiatan yang meliputi perencanaan kebutuhan dan penganggaran, pengadaan, penggunaan, pemanfaatan, pengamanan dan pemeliharaan, penilaian, pemindah tanganan, pemusnahan, penghapusan, penatausahaan dan pembinaan, pengawasan dan pengendalian.

Dinas Perumahan Kawasan Permukiman Dan Pertanahan Kabupaten Toraja Utara sebagai salah satu dinas yang memiliki tugas dan fungsi dalam hal mengatur Kawasan permukimanan dan pertanahan yang ada di Kabupaten Toraja Utara. Dalam menjalankan roda organisasi tentu menggunakan barang miliki negara/daerah. Pada Dinas Perumahan Kawasan Permukiman Dan Pertanahan Kabupaten Toraja Utara setidaknya memiliki asset yang berupa peralatan dan mesin sebagaimana tercatat dalam laporan neraca asset yang dimiliki.

Dalam pelaksanan penatausahaan barang milik daerah pada Dinas Perumahan Kawasan Permukiman Dan Pertanahan Kabupaten Toraja Utara masih belum berjalan dengan baik, ini dapat dilihat dalam penerapan penatausahaan masih ditemukan kekurangan. banyak hal pada pelaksanaan penatausahaan barang milik daerah pada Dinas Perumahan Kawasan Permukiman Dan Pertanahan Kabupaten Toraja Utara memiliki persoalan adanya aset yang berpindah-pindah ruangan sehingga tidak diketahui keberadaannnya dan berdampak pada catatan pengelolaan aset yang tidak menujukan data rill di lapangan. Berdasarkan tabel 1. dimana barang-barang tersebut sering berpindahpindah, baik dari ruangan yang yang satu ke ruangan yang lain atau dari pegawai ke pegawai yang lain tanpa sepengetahuan pengurus barang. 
Tabel 1

Daftar Barang Yang Sering BerpindahPindah dan Hilang

\begin{tabular}{cll}
\hline No & \multicolumn{1}{c}{$\begin{array}{c}\text { Nama / Jenis } \\
\text { Barang }\end{array}$} & \multicolumn{1}{c}{ Keterangan } \\
\hline $\mathbf{1}$ & $\begin{array}{l}\text { Meja Kerja Setengah } \\
\text { Biro }\end{array}$ & $\begin{array}{l}\text { Sering Berpindah } \\
\text { Ruangan }\end{array}$ \\
\hline $\mathbf{2}$ & Kursi Kerja & $\begin{array}{l}\text { Sering Berpindah } \\
\text { Ruangan }\end{array}$ \\
\hline $\mathbf{3}$ & Printer & $\begin{array}{l}\text { Sering Berpindah } \\
\text { Ruangan }\end{array}$ \\
\hline $\mathbf{4}$ & Laptop & $\begin{array}{l}\text { Sering Berpindah } \\
\text { Ruangan }\end{array}$ \\
\hline $\mathbf{5}$ & Global Positioning & Hilang \\
& System (GPS) & Hilang \\
\hline $\mathbf{6}$ & Kamera DSLR & Hilang \\
\hline $\mathbf{7}$ & Kamera Digital & Hilang \\
\hline $\mathbf{8}$ & Mesin Potong & Rumput \\
\hline $\mathbf{9}$ & Speaker Portable & Hilang \\
\hline Sum &
\end{tabular}

Sumber : DPKPP Kab. Toraja Utara

Hal ini disebabkan oleh karena tidak adanya Surat Keputusan yang mengatur tentang siapa saja yang menggunakan barang pada Dinas Perumahan Kawasan Permukiman dan Pertanahan, sehingga pegawai merasa bebas memindahkan barang dari satu ruangan ke ruangan yang lain. Belum adanya juga kartu inventaris ruangan dalam setiap ruangan (KIR) yang menjadi pedoman dan petunjuk tentang jenis dan jumlah barang yang ada dalam suatu ruangan menyebabkan barang-barang tersebut sulit dikontrol keberadaannya dan kepastian barang tersebut harus terletak pada ruangan yang mana. Disamping itu tidak adanya kartu kontrol barang keluar/pinjaman jika ada barang yang akan digunakan atau dipinjam oleh pegawai dalam rangka tugas di lapangan mengakibatkan barang tersebut sulit diketahui keberadaanya apabila sudah berpindah dari tangan ke tangan akhirnya tidak jelas lagi keberadaan barang tersebut. Adapun tujuan dari penelitian adalah untuk mengetahui penatausahaan barang milik daerah Pada Dinas Perumahan Kawasan Permukiman Dan Pertanahan Kabupaten Toraja Utara.

\section{METODE PENELITIAN}

Dalam penelitian ini pendekatan penelitian yang digunakan adalah pendekatan kualitatif. Adapun teknik pengumpulan data yang digunakan yaitu wawancara, observasi dan telaah dokumen. Informan dalam penelitian ini sebanyak sepuluh orang yaitu Kepala Dinas, Sekertrais Dinas, Kabid Aset BPKAD, Inspektorat, Kasubag Keuangan, Kasubag Program dan Anggaran, Kepala Bidang Penyehatan Lingkungan, Kepala Bidang Permukiman, Pengurus Barang dan Staf. Sumber data dalam penelitian ini terdiri atas data primer dan data sekunder. Sedangkan teknik analisis data yang digunakan dalam peneliitian ini meliputi, pengumpulan data, reduksi data, penyajian datan dan penarikan kesimpulan. 


\section{HASIL PENELITAN}

\section{Pembukuan}

Pada setiap instansi pemerintah daerah tentu harus melakukan penatausahaan barang milik daerah yang ada pada dinasnya masing-masing. Karena itu, setiap instansi tentunya wajib melakukan pembukuan atau pencataan yang baik atas setiap aset-aset yang dimiliki di instansi masing-masing tanpa terkecuali seperti halnya pada Dinas Perumahan Kawasan Permukiman Dan Pertanahan Kabupaten Toraja Utara juga harus melakukan pembukuan atas asset yang dimilikinya. Pencataan atas aset harus dilakukan dengan baik dan jujur sesuai dengan kondisi yang terjadi dilapangan tentang aset yang dimiliki baik dari segi jumlah atau status keberadaan barang (hilang, berfungsi dengan baik atau sudah rusak).

Proses pencataan barang milik daerah yang dilakukan di kantor DPKPP Kabupaten Toraja Utara sebagaimana disampaikan oleh Tomi Toding Pata, ST selaku Staf mengatakan bahwa:

"Proses pencatatan barang milik daerah tidak jelas, pada saat ada pengadaan barang tidak langsung dicatat oleh bendahara pengurus barang. Pencatatan dan pembukuan barang milik daerah belum dilakukan dengan baik. (wawancara, 3 Agustus 2020)".

Dari penyataan tersebut, dimana pencatatan yang dilakukan selama ini belum dilakukan dengan baik, dimana pada saat barang atau pada saat pengadaan barang, tidak langsung dicatat kedalam buku pencatatan sehingga memungkinkan barang tidak terdata. Hal sebagaimana berdasarkan hasil observasi yang dilakukan oleh peneliti dimana masih ada barang milik daerah yang belum di catatkan dalam pembukuan sehingga barang tersebut belum tercatat dalam buku inventaris barang milik daerah. untuk lebih jelasnya barang yang tidak tercatat tersebut dapat dilihat pada tabel.

Tabel 2

Pengadaan Kendaraan Dinas Tahun 2020

\begin{tabular}{clc}
\hline No & \multicolumn{1}{c}{ Jenis Barang } & Tanggal SP2D \\
\hline $\mathbf{1}$ & Kendaraan Dinas & $07 / 04 / 2020$ \\
& Operasional Toyota & \\
& Hilux Single Cabin 4 x 2 & \\
\hline $\mathbf{2}$ & Kendaraan Dinas & $07 / 04 / 2020$ \\
& Operasional Toyota & \\
& Double Cabin 4 x 4 &
\end{tabular}

Sumber : DPKPP Kab. Toraja Utara

Berdasarkan Tabel 2 dapat dijelaskan bahwa masih ada barang milik dareah yang berlum dicatat oleh pengurus barang kedalam buku inventaris barang yang semestinya pada saat barang tersebut diterima, maka pengurus barang sudah 


\section{Daniel Sari Patontongan, Frida Chairunisa, dan Nuraeni Sayuti /Jurnal Administrasi Negara, V26 - 03 (2020)/304-326}

harus melakukan pencatatan barang tersebut kedalam buku inventaris sebagai bukti bahwa barang tersebut merupakan barang milik daerah pada kantor DPKPP Kabupaten Toraja Utara.

Dari hasil wawancara dengan Habel Patabang selaku Bendahara Pengurus Barang mengatakan bahwa :

"Proses pencatatan dilakukan dengan manual dan dengan menggunakan aplikasi SIMDA barang (wawancara, 4 Agustus 2020)”.

Menurut Apes Jhon Sampe, S.Kom selaku Kepala Sub bagian Keuangan mengatakan bahwa:

"Pencatatan barang dilakukan setelah barang telah diterima dari pihak penyedia barang dan setelah semua dokumen lengkap, kemudian bendahara pengurus barang mencatat kedalam daftar pengadaan dan barang dengan menginput pada SIMDA barang (wawancara, 6 Agustus 2020)".

Dari apa yang disampaikan oleh informan tersebut dimana pencatatan barang masih dilakukan secara manual dan kemudian di input kedalam SIMDA, pencatatan barang dilakukan secara manual setelah barang diterima dari pihak penyedia dan disertai dengan dokumen yang dukung data sekunder sudah lengkap. Dari hasil pengamatan yang dilakukan oleh peneliti dimana pencataan dilakukan secara manual kemudian diinput oleh bendahara pengurus barang ke aplikasi SIMDA di BPKAD Kabupaten Toraja Utara, aplikasi SIMDA pada laptop bendahara tidak efektif digunakan untuk penginputan data oleh karena tidak terintegrasi langsung ke SIMDA pada server di BPKAD Kabupaten Toraja Utara, apabila data pada aplikasi SIMDA pengurus barang diekspor ke server, maka data SIMDA BPKAD Kabupaten Toraja Utara akan tertimpa, oleh sebab itu untuk saat ini semua pengurus barang masing-masing OPD masih disarankan untuk datang langsung ke Bidang Aset BPKAD Kabupaten Toraja Utara melakukan penginputan langsung ke server SIMDA BMD Bidang Aset BPKAD Kabupaten Toraja Utara.

Berdasarkan observasi yang
dilakukan bahwa pembukuaan yang
dilakukan pada kntor DPKPP Kabupaten
Toraja Utara dimana semua barang dicatat namun bukti fisiknya masih ada yang tidak jelas keberadaannya. Hal ini terjadi karena pengurus barang dalam melakukan pembukuan hanya berpedoman pada bukti dokumen saja tanpa perna melakukan croscek atas barang yang dibukukan tersebut. Selain itu, pencatatan dan pembukuan belum dilakukan dengan baik oleh pengurus barang sehingga barang 
tidak tercatat kedalam pembukuan maupun dalam SIMDA sehingga barang tersebut tidak terdata keberadaannya, dikarenakan tidak adanya SK penunjukan pengguna barang yang tetapkan oleh kepala dinas yang menetapkan siapa saja yang menggunakan barang atau peratalan kantor, sehingga tidak jelas siapa yang bertanggaung jawab atas setiap peralatan kantor yang digunakan. Hal lain yang menyebabkan pencatatan dan pembukuan belum terlalu maksimal dilakukan disebabkan karena data dokumen atau bukti beberapa barang masih dipegang oleh pegawai yang sudah dimutasi ke OPD lain yang semestinya barang tersebut harus di kembalikan. Selain itu dalam proses penginputan barang pada SIMDA harus dilakukan di kantor Badan Pengelola Keuangan dan Aset Daerah Kabupaten Toraja Utara sebagai penyedia aplikasi SIMDA dan di input secara manual oleh pengurus barang dan dalam proses penginputan dilakukan secara bergantian dengan pengurus barang dari dinas lain. hal inilah yang menjadi salah satu penyebab keterlambatan dalam pembukuan yang dilakukan oleh pengurus barang.

Dalam proses pembukuaan atau pencatatan barang yang dilakukan pada Kantor DPKPP Kabupaten Toraja Utara yang belum terlaksana dengan baik disebabkan karena belum adanya standar prosedur yang menjadi pedoman dalam pencatatan barang, selain itu, terlambatnya dokumen dari PPTK sehingga menghambat proses pencatatan. Hal ini sebagaimana disampaikan oleh Habel Patabang selaku bendahara pengurus barang menyatakan kendala atau hambatan dalam hal pencataan atau pembukuan barang milik daerah yaitu

"Belum ada standar prosedur untuk menjadi pedoman dalam pencatatan dan pembukuan barang. Para PPTK tidak segera menyerahkan dokumendokumen yang terkait dengan pengadaan barang sehingga menghambat pencatatan (wawancara, 4 Agustus 2020)'”.

Menurut k Apes Jhon Sampe, S.Kom selaku Kepala Sub bagian Keuangan mengatakan bahwa:

"Kendala dalam pencatatan barang adalah dokumen pengadaan barang kadang-kadang tidak lengkap, selain itu, bendahara pengurus barang tidak tertib mencatat setiap pengadaan barang sehingga barang kadang tidak tercatat (wawancara, 6 Agustus 2020)".

Sedangkan menurut Bapak Sutrisno Parintak, SE, M.Si selaku Kepala Bidang Aset pada BPKAD mengatakan bahwa;

"Belum adanya standar operasional prosedur yang dimiliki Dinas Perumahan Kawasan permukiman dan Pertanahan tentang pencatatan dan pembukuan barang milik daerah 


\section{Daniel Sari Patontongan, Frida Chairunisa, dan Nuraeni Sayuti /Jurnal Administrasi Negara, V26 - 03 (2020)/304-326}

membuat pengurus barang belum melakukan pencatatan dan pembukuan dengan baik (wawancara, 26 Agustus 2020)".

Dari pernyataan tersebut diatas, bahwa kendala yang dihadapi dalam proses pembukuaan atau pencatatan barang milik daerah adalah belum adanya pedoman pembukuan yang diberikan kepada setiap pengurus barang, selain itu Para PPTK tidak segera menyerahkan dokumendokumen yang terkait dengan pengadaan barang, belum lagi dokumen barang yang tidak lengkap serta lambanya pengurus barang dalam melakukan pencatatan barang milik daerah. Hal ini terjadi di karenakan PPTK tidak kooperatif dan belum memahami sepenuhnya tentang pentingnya dokumen pengadaan barang untuk diserahkan kepada bendahara pengurus barang sebagai bahan untuk pencatatan dan pembukuan barang milik daerah. Karena data-data dari dokumenlah yang akan diinput oleh bendahara pengurus barang.

\section{Inventarisasi}

Inventarisasi barang milik daerah harus dilakukan sebagai upaya untuk menjaga atau mengamankan barang miliki daerah agar tidak disalah gunakan atau dihilangkan. Penginventarisasian barang merupakan hal yang mesti dilakukan oleh setiap instansi atau dinas tanpa terkecuali. Seperti halnya pada kantor Dinas Perumahan Kawasan Permukiman Dan Pertanahan Kabupaten Toraja Utara harus melakukan inventarisasi barang dengan baik sehingga barang-barang yang ada di dalam lingkungan dinas bisa terdata dengan baik, terutama dari segi jumlah, lokasi barang serta kondisi barang.

Wawancara dengan bapak Tomi Toding Pata, ST selaku Staf mengatakan bahwa:

"Barang-barang tidak terinventarisir dengan baik, pengadaan barang beberapa tahun lalu sudah banyak yang tidak jelas keberadaanya dan siapa yang menggunakannya (wawancara, 3 Agustus 2020)".

Wawancara dengan bapak Habel Patabang selaku bendahara pengurus barang mengatakan bahwa:

"Saya sulit melakukan proses inventarisasi semua barang karena ada beberapa barang yang tidak jelas keberadaannya karena sering berpindah tangan (wawancara, 4 Agustus 2020)".

Wawancara dengan bapak Beny Turo Kendekallo, ST selaku Kepala Bidang Permukiman mengatakan bahwa:

"Pengurus barang melakukan pendataan barang disetiap bidang, namun beberapa barang yang akan didata tidak jelas keberadaannya (wawancara, 12 Agustus 2020)". 
Berdasarkan apa yang disampaikan oleh informan tersebut, maka bisa dikatakan bahwa kegiatan inventarisasi barang di DPKPP Kabupaten Toraja Utara belum dilakukan dengan baik dimana barang-barang yang beberapa tahun lalu Sebagian telah hilang atau tidak jelas keberadaannya karena seringnya berpindah tangan tanpa ada pemberitahuan atau izin peminjaman atau penggunaan barang kepada pengurus barang sehingga barangbarang tersebut tidak terdata.

Menurut Ir. Kristian Yunianto Mendeng, MT selaku Sekretaris DPKPP Kabupaten Toraja Utara bahwa:

"Inventarisasi barang milik daerah pada Dinas Perumahan belum dilakukan dengan baik oleh karena keterbatasan sumber daya yang dimiliki serta belum adanya standar operasional prosedur dalam penatausahaan barang milik daerah yang dimiliki oleh Dinas Perumahan yang akan menjadi pedoman bendahara pengurus barang dalam melaksanakan tugasnya_(wawancara, 14 Agustus 2020)".

Menurut Bapak Sutrisno Parintak, SE, M.Si selaku Kepala Bidang Aset BPKAD mengatakan bahwa:

"Pengurus barang Dinas Perumahan belum menyajikan data yang detail dan akurat tentang barang milik daerah yang dikelolah, sehingga data barang yang diinput pada aplikasi simda barang tidak memberikan informasi yang jelas mengenai status rill barang tersebut (wawancara, 26 Agustus 2020)".

Dalam penginventarisasian barang milik daerah agar mudah di data yaitu dengan memberikan label kode pada setiap barang. Label kode barang inventaris bertujuan untuk mengamankan dan memberikan kejelasan status kepemilikan dan status penggunaan barang pada masing-masing pengguna. Label kode barang inventaris di kantor DPKPP Kabupaten Toraja Utara terdapat kode lokasi dan kode barang. Barang inventaris yang berada di Dinas Perumahan Kawasan Permukiman Dan Pertanahan Kabupaten Toraja Utara tidak semuanya terdapat label kode barang inventaris.

Berdasarkan wawancara dengan Bapak Tomi Toding Pata, ST selaku Staf mengatakan bahwa:

"Ada beberapa barang yang memilki label atau kode ada juga yang tidak (wawancara, 3 Agustus 2020)".

Wawancara dengan bapak Habel Patabang selaku bendahara pengurus barang mengatakan bahwa:

"Belum semua barang memiliki kode dan label, beberapa yang sudah memiliki label yang dipasang beberapa tahun lalu saat diadakan sensus barang milik daerah oleh $B P K A D$, itupun sekarang labelnya sudah ada yang lepas atau tidak bisa terbaca lagi (wawancara, 4 Agustus 
2020)"

Wawancara dengan Bapak Ir. Kristian Yunianto Mendeng, MTselaku Sekretaris mengatakan bahwa

"Baru ada beberapa yang saya perhatikan memiliki label, tentunya kedepannya akan diusahakan untuk memberi kode dan label pada semua barang (wawancara, 14 Agustus 2020)".

Apa yang disampaikan oleh para informan dari Dinas Perumahan Kawasan Permukiman Dan Pertanahan Kabupaten Toraja Utara juga di benarkan oleh bapak Manase Pongtasik, ST selaku Auditor Madya Inspektorat Kabupaten Toraja Utara mengatakan bahwa:

"Baru beberapa barang yang memiliki label dan kode, label tersebut terpasang saat dilakukan sensus BMD bersama dengan Tim dari Bidang Aset beberapa tahun yang lalu (wawancara, 27 Agustus 2020)".

Dari pernyataan tersebut, bahwa pada dinas DPKPP Kabupaten Toraja Utara baru sebagian barang milik daerah yang memiliki kode atau label yang terpasang pada barang tersebut. pemasangan kode atau lebel tersebut baru dilakukan ketika akan dilakukan sensus BMD bersama dengan Tim dari Bidang Aset. Itu artinya masih ada barang milik daerah yang tidak memilik kode atau label. Karena itu, perlu adanya upaya pembuatan kode atau label untuk kemudian ditempelkan pada setiap barang milik daerah sehingga nantinya data inventaris barang bisa terdata secara akurat.

Berdasarkan observasi yang dilakukan bahwa pada Kantor DPKPP Kabupaten Toraja Utara memang baru sebagaian barang milik daerah yang memiliki label atau kode barang. Selama ini petugas barang milik daerah jarang melakukan pembuatan label atau kode barang untuk setiap barang yang ada di kantor dinas. Dalam pembuatan label atau kode barang tentu ditandai dengan adanya pemberian nomor pada setiap barang milik daerah sebagai salah satu bukti bahwa barang tersebut adalah barang milik daerah yang berada di DPKPP Kabupaten Toraja Utara sebagai bukti bahwa barang tersebut merupakan barang milik daerah yang beradah di lingkup DPKPP Kabupten Toraja Utara.

Selain pembuatan label kode barang dalam melakukan inventarisasi aset, hal lain yang juga bisa dilakukan adalah dengan membuat rekap daftar barang ruang merupakan selembar kartu hasil cetakan data barang yang ditempelkan di masingmasing ruangan. Setiap ruangan yang ada di Kantor DPKPP Kabupaten Toraja Utara mestinya terdapat rekap daftar barang yang 


\section{Daniel Sari Patontongan, Frida Chairunisa, dan Nuraeni Sayuti /Jurnal Administrasi Negara, V26 - 03 (2020)/304-326}

terdapat dalam ruangan yang dimana menjelaskan nama barang yang ada dalam ruangan tersebut bahkan jumlah barangnya, namum pada kenyataanya pada kantor DPKPP Kabupaten Toraja Utara tidak terdapat rekap daftar barang ruang. Hal ini sebagaimana disampaikan oleh Bapak Wempi Bako, ST selaku Kepala Sub Bagian Program dan Anggran mengatakan bahwa

"Tidak ada rekap daftar barang khusunya diruangan saya begitu juga di ruangan yang lainnya (wawancara, 11 Agustus 2020)".

Wawancara dengan Beny Turo Kendekallo, ST Kepala Bidang Permukiman

"Belum ada daftar rekap barang dalam ruangan yang terdapat disetiap ruang kerja yang ada di kantor dinas ini (wawancara, 12 Agustus 2020)".

Begitu juga yang disampaikan oleh Manase Pongtasik, ST selaku Auditor Madya Inspektorat Kabupaten Toraja Utara

"Pada Dinas Perumahan belum terdapat daftar rekap barang dalam setiap ruangan (wawancara, 27 Agustus 2020)".

Dari apa yang disampaikan diatas, bahwa setiap ruang pada Kantor DPKPP Kabupaten Toraja Utara tidak terdapat rekap daftar barang ruang. Rekap daftar ruang adalah catatan yang berisi barang- barang yang ada dalam ruangan yang bertujuan untuk mengetahui barang apa saja yang terdapat dalam ruang tersebut.

Berdasarkan observasi yang dilakukan bahwa apa yang telah di sampaikan oleh para informan diatas, memang benar adanya, dimana disetiap ruangan yang ada pada Kantor DPKPP Kabupaten Toraja Utara tidak tersedia rekap daftar barang. Ketidaktersedian daftar barang ini disebabkan karena petugas yang bertanggungjawab dalam penatausahaan barang pada kantor DPKPP Kabupaten Toraja Utara belum atau tidak membuat rekap daftar barang yang ada di setiap ruang dengan alasan karena seringnya barang berpindah dari ruang ke ruangan lain.

Aspek lain yang juga mesti dilakukan dalam inventarisasi barang milik daerah adalah dengan membuat kartu inventaris barang. Kartu inventaris barang yang memuat data barang milik daerah yang digunakan untuk mengontrol barang milik DPKPP Kabupaten Toraja Utara. Oleh karena itu, pembuatan kartu invetaris barang sangat penting dilakukan sebagai upaya untuk memperjelas barang miliki daerah.

Berdasarkan wawancara dengan Bapak Tomi Toding Pata, ST selaku staf 
mengatakan bahwa:

"Tidak ada Kartu Inventaris Ruangan di tiap-tiap ruangan. Bendahara pengurus barang tidak membuat kartu inventaris ruangan (wawancara, 3 Agustus 2020)".

Wawancara dengan Bapak Habel Patabang selaku bendahara pengurus barang mengatakan bahwa:

"Saya belum membuat kartu inventaris ruangan, karena pegawai seenaknya memindahkan beberapa barang ke tempat lain tanpa sepengetahuan saya. adapun yang termuat dalam kartu inventaris ruangan Nama barang, jumlah barang, spesifikasi dan tahun pengadaan barang (wawancara, 4 Agustus 2020)".

Hal yang sama juga disampaikan oleh Wempi Bako, ST Selaku Kepala Sub Bagian Program dan Anggran bahwa:

Tidak ada kartu inventaris barang di masing-masing ruangan (wawancara, 11 Agustus 2020).

Berdasarkan observasi yang dilakukan bahwa selain tidak tersedia daftar rekap barang disetiap ruangan pada kantor DPKPP Kabupaten Toraja Utara juga tidak tersedia kartu inventaris ruangan (KIR) yang semes tinya harus dibuat oleh pengurus barang sebagai salah satu cara untuk mendata daftar inventaris barang yang ada di kantor, namum pada kenyataannya hal ini tidak dilakukan oleh pengurus barang tanpa alasan yang jelas, pada hal ini menjadi salah satu tunggungjawab dari pengurus barang yang harus dilakukan dalam upaya melakukan penatausahaan barang milik daerah dengan baik

\section{Pelaporan}

Dalam penatausahan barang milik daerah, salah satu aspek yang juga penting dilakukan adalah tersedianya laporan secara berkala atas barang milik daerah yang ada di instansi. Laporan ini merupakan sebagai salah satu bentuk pertanggunjawaban atas penggunaan barang milik daerah. Dengan adanya laporan barang milik daerah maka tentu akan diketahui seperti apa gambaran barang miliki daerah yang ada setiap Dinas baik dari segi jumlah, kondisinya. Pelaksanaan pelaporan merupakan akhir dari pelaksanaan inventarisasi. Pelaksanaan pelaporan inventarisasi dilakukan terus menerus setiap tahunnya.

Berdasarkan wawancara dengan Habel Patabang selaku pendahara pengurus barang tentang bagaimana pelaksanaan pelaporan barang miliki daerah pada kantor DPKPP Kabupaten Toraja Utara?

"Pelaporan barang milik daerah dilakukan tiap semesteran dan tahunan ke BPKAD namun selalu tidak tepat waktu (wawancara, 4 Agustus 2020)". 
Wawancara dengan Bapak Apes Jhon Sampe, S.Kom selaku Kepala Sub bagian Keuangan mengatakan bahwa:

"Laporan barang milik daerah disampaikan ke Bidang Aset pada Badan Pengelolah Keuangan dan Aset Daerah (wawancara, 6 Agustus 2020)".

Sedangkan menurut bapak Wempi Bako, ST selaku Kepala Sub Bagian Program dan Anggaran mengatakan bahwa:

"Dinas perumahan sering mendapat teguran oleh karena selalu terlambat menyampaikan laporan barang (wawancara, 11 Agustus 2020)”.

Dari apa yang telah disampaikan oleh para informan tersebut diatas, dimana pada kantor DPKPP Kabupaten Toraja Utara selalu membuat laporan persemester dan tahunan yang kemudian laporan tersebut diberikan kepada BPKAD Kabupaten Toraja Utara, namum laporan yang diberikan oleh pengurus barang DPKPP Kabupaten Toraja Utara sering terlambat disampaikan atau dilaporkan kepada BPKAD Kabupaten Toraja Utara sehingga sering kali mendapat teguran secara lisan. Keterlambatan pelaporan barang miliki daerah pada DPKPP Kabupaten Toraja Utara disebabkan karena bendahara pengurus barang tidak disiplin dalam melakukan pelaporan data barang miliki daerah.
Hal ini sejalan dengan apa yang sampaikan oleh Bapak Manase Pongtasik, ST selaku Auditor Madya Inspektorat Kabupaten Toraja Utara

"Dinas perumahan adalah salah satu Dinas yang tidak tepat waktu menyampikan laporan, baik semesteran dan laporan tahunan (wawancara, 27 Agustus 2020)".

Begitu juga dengan yang disampaikan oleh Bapak Sutrisno Parintak, SE, M.Si selaku Kepala Bidang Aset pada BPKAD mengatakan bahwa:

"Bendahara pengurus barang Dinas Perumahan tidak disiplin dalam menyampaikan laporannya, laporan yang disampaikan pada dasarnya sudah sesuai dengan ketentuan yang berlaku (wawancara, 26 Agustus 2020)".

Dari apa yang disampaikan oleh kedua informan tersebut diatas, maka bisa dikatakan bahwa pada Dinas Perumahan Kawasan Permukiman Dan Pertanahan Kabupaten Toraja Utara merupakan salah satu OPD yang sering tidak tepat waktu dalam menyampaikan laporan.

Dalam proses pelaporan barang milik daerah tentu dibutuhkan koodinasi antara semua pihak yang dalam instansi, karena tanpa adanya koordinasi yang baik antara semua pihak maka tentu pelaporan akan inventarisasi barang miliki daerah tentu tidak akan maksimal. Karena itu, 
koordinasi merupakan salah satu aspek yang harus dilakukan oleh para pengurus barang dalam proses penyusunan laporan barang miliki daerah

Wawancara dengan bapak Beny Turo Kendekallo, ST selaku Kepala Bidang Permukiman mengatakan bahwa:

"Seharusnya pengurus barang melakukan koordinasi ke masingmasing bidang untuk mengecek keberadaan barang sebelum membuat laporan namun hal itu tidak dilakukan (wawancara, 12 Agustus 2020)”.

Begitu juga yang disampaikan oleh bapak Anton Palungan, ST selaku Kepala Bidang Penyehatan Lingkungan

"Bendahara pengurus barang tidak melakukan koordinasi ke bidangbidang sebelum membuat laoran barang milik daerah (wawancara, 10 Agustus 2020)".

Hal yang tidak jauh berbeda denga apa yang disampaikan oleh bapak Ir. Kristian Yunianto Mendeng, MT selaku Sekretaris Mengatakan bahwa:

"Bendahara pengurus barag kurang berkoordinasi dengan sekretaris saat membuat laporan barang milik daerah sebelum diserahkan ke kepala Dinas (wawancara, 14 Agustus 2020)".

Dari apa yang telah disampaikan oleh para informan tersebut diatas dimana koordinasi yang dilakukan oleh pengurus barang dalam pelaporan barang milik daeah di Dinas Perumahan Kawasan Permukiman Dan Pertanahan Kabupaten Toraja Utara belum berjalan dengan baik, dimana pengurus barang sebagai orang yang bertanggunjawab dalam membuat atau melaporkan barang jarang melakukan koordinasi dengan para pegawia disetiap ruangan dalam proses penyusunan laporan barang miliki daerah, atau dengan kata lain pihak pengurus barang tidak pernah melibatkan pegawai atau kepala bagian yang ada di Dinas untuk membantu mengecek keberadaan barang milik daerah yang ada disetiap ruangan. Jadi selama ini laporan barang miliki daerah yang dibuat oleh petugas pengurus barang dibaut tanpa ada pelibatan dari bidan-bidan yang ada di DPKPP Kabupaten Toraja Utara dan laporan tersebut biasanya langsung diserahkan kepada kepala dinas.

Dalam membuat laporan atau memberikan pelaporan tentang barang milik daerah maka tentu harus dibaut dengan jujur sesuai dengan kondisi dan fakta-fakta yang ada. Karena itu, perlu adanya koordinasi yang baik antara semua lini yang ada di dinas agar laporan yang disajikan betul-betul sesuai dengan kondisi yang sebenaranya. Dalam membuat laporan barang milik daerah, koordinasi tidak hanya 
dilakukan dengan unsur yang ada didalam lingkungkan dinas, tetapi juga perlu ada koordinasi dengan Inspektorat Kabupaten dan BPKAD.

Hal ini sebagaimana disampaikan oleh Manase Pongtasik, ST selaku Auditor Madya Inspektorat Kabupaten Toraja Utara mengatakan bahwa

"Bendahara pengurus barang harus melakukan koordinasi dengan Inspektorat Kabupaten sebelum menyampaikan laporan barang milik daerah untuk diadakan rekonsiliasi barang milik daerah sebelum disampaikan ke BPKAD (wawancara, 27 Agustus 2020)".

Koordinasi dengan inspektoran dengan tujuan untuk melihat apakah laporan barang yang dibuat saat ini betulbetul sudah sesuai dengan apa yang ada dilapangan. Jika ada data laporan yang sekiranya tidak berkesuaian dengan kondisi yang sebenarnya maka tentu harus dilakukan perbaikan. Dalam Menyusun laporan penatusahan barang milik daerah bukanlah pekerjaan yang mudah untuk dilakukan, karena dalam proses penyusunan laporan ini tentu dibuat dengan mengacu pada data yang dari proses pembukukaan, penginventarisasian sampai pada akhirnya di buatkan laporan sebagai bentuk pertanggungjawaban atas penggunaan barang milik daerah yang ada pada Dinas Perumahan Kawasan Permukiman Dan Pertanahan Kabupaten Toraja Utara.

Menurut Habel Patabang selaku bendahara pengurus barang mengatakan bahwa kendala yang ditemui dalam pelaksanaan pelaporan barang miliki daerah, yaitu:

“1) Kendalanya yaitu waktu penyampaian laporan sangat singat sedangkan saya membutuhkan waktu untuk membuat laporan; 2) PPK/PPTK selalu lambat meberikan data dan dokumen tentang hasil pengadaan baik barang maupun konstruksi; serta 3) Laporan saya kerjakan sendiri tanpa dibantu staf (wawancara, 4 Agustus 2020)".

Menurut Apes Jhon Sampe, S. Kom selaku Kepala Sub bagian Keuangan mengatakan bahwa:

“1) Lambatnya bendahara pengurus barang dalam merampungkan laporan semesteran maupun Tahunan; 2) Kurang kooperatifnya pegawai pengguna barang dalam menyampikan keadaan atau kondisi barang yang digunakan; 3) Dokumen pendukung pengadaan barang yang sering lambat diterima oleh bendahara pengurus barang; dan 4) Belum adanya standar operasional prosedur sebagai pedoman penyusunan dan penyampaian laporan barang milik daerah (wawancara, 6 Agustus 2020)".

Dari apa yang disampaikan oleh informan tersebut bahwa dalam pelaporan 
barang miliki daerah yang menjadi kendala adalah batas waktu yang diberikan untuk menyelesaikan laporan yang dibuat cukup singkat sehingga laporan kadang terlambat di sampaikan, selain itu kooperatifnya pegawai pengguna barang dalam menyampikan keadaan atau kondisi barang yang digunakan serta adanya keterlambatan dalam penyerahan dokumen pendukung pengadaan barang kepada bendahara pengurus barang. Kendala-kendala ini tentu harus bisa diatas dan terus dilakukan perbaikan agar nantinnya pelaporan barang milik daerah pada DPKPP Kabupaten Toraja Utara bisa lebih tepat waktu dan data yang disajikan dalam laporan betulbetul akurat sesuai dengan kondisi yang ada

\section{Sumber Daya Manusia}

Dalam melaksanakan penatausahan barang milik daerah tentu harus dilakukan dengan baik dan benar sesuai dengan aturan yang berlaku. Oleh karena itu, dalam melakukan penatausahan barang milik daerah tentu harus dilakukan oleh sumber daya manusia (pegawai) yang berkompeten yang memiliki pengetahuan tentang penatausahaan barang. Jika petugas atau pegawai yang ditempatkan untuk melakukan penatausahaan barang milik daerah tidak memiliki kemampuan atau pengetahuan yang memadai dalam melakukan penatausahaan, maka tentu akan berdampak pada tidak maksimalnya penatausahaan barang milik daerah.

Berdasarkan wawancara yang dilakukan dengan Bapak Ir. Daniel Tandi selaku Kepala Dinas Perumahan Kawasan Permukiman Dan Pertanahan Kabupaten Toraja Utara tentang bagaimana proses penetapan pejabat yang mengurus barang milik daerah pada Dinas Perumahan Kawasan permukiman dan Pertanahan Mengatakan bahwa:

"Calon bedahara pengurus barang diusul ke Bupati melalui BPKAD dan ditetapkan oleh keputusan Bupati (wawancara, 24 Agustus 2020)".

Wawancara dengan Bapak Sutrisno Parintak, SE, M.Si selaku Kepala Bidang Aset pada BPKAD mengatakan bahwa:

"Masing-masing perangkat daerah yang mengusulkan calon bendahara pengurus barang ke Bupati melalui BPKAD dan ditetapkan melalui Keputusan Bupati (wawancara, 26 Agustus 2020)".

Menurut bapak Manase Pongtasik,

ST selaku Auditor Madya Inspektorat Kabupaten Toraja Utara mengatakan bahwa:
"Masing-masing OPD mengusul calon bendaharawan secara koektif termasuk bendahara pengurus barang ke Bupati melalui BPKAD 
(wawancara, 27 Agustus 2020)”.

Sebagaimana yang telah disampaikan oleh informan tersebut, bahwa dalam memilih bendahara pengurus barang yang nantinya akan melakukan penatausahaan barang milik daerah di pilih dari pegawai pada instansi atau OPD masing-masing di setujui oleh kepala dinas dan diajaukan atau dikrim kepada Bupati melalui Badan Pengelolah Keuangan dan Aset Daeah untuk kemudian mendapatkan persetujuan untuk ditetapkan sebagai bendahara pengurus barang milik daerah.

Berdasarkan observasi yang dilakukan bahwa dalam hal penetapan bendahara pengurus barang yang dilakukan di DPKPP Kabupaten Toraja Utara di tunjuk atau di rekomendasikan oleh kepala dinas sendiri, yang kemudia nama pengurus barang tersebut dikrim ke Badan Pengelolah Keuangan dan Aset Daeah untuk kemudia diberikan surat tugas untuk melakukan penatausahan barang miliki daerah.

Dalam upaya meningkatkan pengetahuan petugas dalam melakukan penatausahaan barang milik daerah, maka tentu harus mengikuti kegiatan diklat atau pelatihan terkait dengan penatausahaan barang milik daerah sehingga dapat nantinya mengaplikasi penatausahan barang dengan baik. Namum pada kenyataanya petugas yang bertanggungjawab dalam melaksanakan penatausahaan barang milik daerah tidak pernah mendapatkan atau mengikuti kegiatan pelatihan tentang cara melakukan penatausahaan barang milik daerah sesuai dengan aturan yang berlaku, selama ini petugas hanya mengikuti kegiatan sosialisasi tentang pengelolaan asset milik daerah.

Tabel 3

Kodisi SDM Pengurus Barang Milik Daerah

\begin{tabular}{cccc} 
No & $\begin{array}{l}\text { Pengurus } \\
\text { Barang }\end{array}$ & $\begin{array}{c}\text { Kegiatan } \\
\text { pernah } \\
\text { Diikuti }\end{array}$ & Ket \\
\hline & & $\begin{array}{c}\text { Sosialisasi } \\
\text { peraturan } \\
\text { barang milik } \\
\text { daerah }\end{array}$ & $\begin{array}{c}\text { Tidak pernah } \\
\text { mengikuti } \\
\text { bimbingan teknis } \\
\text { penatausahan } \\
\text { barang milik } \\
\text { daerah. }\end{array}$ \\
\hline
\end{tabular}

Sumber : Data Sekunder, 2020.

Berdasarkan Tabel 3 tersebut diatas, bahwa jumlah pengurus barang yang mengurus barang milik daerah pada Dinas Perumahan Kawasan Permukiman Dan Pertanahan Kabupaten Toraja Utara hanya satu orang saja yaitu bapak Habel Patabang, namum pengurus barang belum pernah mengikuti pelatihan atau diklat terkait dengan penatausahaan barang milik daerah disebabkan karena belum pernahnya pemerintah daerah dalah hal ini BPKAD tidak perna melaksankan kegiatan pelatihan 
terkait penatausahaan barang. Kegiatan yang pernah dilakukan hanya berupa kegiatan sosialisasi tentang peraturan barang milik daerah.

Hasil wawancara dengan bapak Habel Patabang selaku bendahara pengurus barang mengatakan bahwa:

"Saya baru mengikuti sosialisasi Permendagri Nomor 19 tahun 2016, saya belum pernah mengikuti bimbingan teknis atau pelatihan khusus penatausahaan dan pengelolaan barang milik daerah (wawancara, 4 Agustus 2020)"

Begitu juga dengan apa yang disampaikan oleh bapak Ir. Kristian Yunianto Mendeng, MT selaku Sekretaris mengatakan bahwa:

"Selama ini, pengurus barang belum pernah diikutkan, hanya focus pada diklat pengadaan barang dan jasa, namun kedepannya akan diupayakan untuk mengikutkan bendahara pengurus barang mengikuti diklat dan pelatihan pengelolaan barang (wawancara, 4 Agustus 2020)"

Hal senada juga disampaikan oleh bapak Ir. Daniel Tandi selaku Kepala Dinas Perumahan Kawasan Permukiman Dan Pertanahan Kabupaten Toraja Utara mengatakan bahwa:

"Belum memperoleh pelatihan namun telah mengikuti sosialisasi peraturan terkait pengelolaan barang milik daerah, dan pada kesempatan berikut akan diikutkan pada diklat atau bimtek pengelolaan barang milik daerah (wawancara, 24 Agustus 2020)"

Berdasarkan apa yang telah disampaikan oleh para informan tersebut, maka bisa dikatakan bahwa selama ini petugas yang mengurusi penatausahan barang milik daerah terutama pada DPKPP Kabupaten Toraja Utara belum pernah mengikuti atau mendapatkan pelatihan terkait penatausahaan barang miliki daerah. Hal disebabkan karena dana untuk kegiatan khusus pelatihan penatausahaan barang milik daerah tidak pernah dianggarkan oleh dinas, begitu juga pada BPKAD selaku penanggungjawab aset pemda yang juga tidak pernah menggarkan untuk kegiatan pelatihan penatausahaan barang milik daerah. adupun yang dianggarakan hanya pada kegiatan sosialisasi tentang pengadaan barang dan jasa. Pada hal kegiatan pelatihan untuk pengurus barang milik daerah sangat penting untuk dilakukan agar pengruus barang bisa mengetahui dengan baik apa yang harus dilakukan dalam penatausahaan barang. Kegiatan yang pernah diikuti oleh petugas penatausahaan barang milik daerah hanya berupa kegiatan sosialisasi tentang pengelolaan barang miliki daerah sesuai dengan aturan yang terbaru.

Apa yang telah diuraikan diatas juga 
dibenarkan oleh bapak Sutrisno Parintak, SE, M.Si selaku Kepala Bidang Aset pada BPKAD mengatakan bahwa:

"Secara keseluruhan belum dilakukan pelatihan atau diklat terkait penatausahaan barang milik daerah kepada bendahara pengurus barang. Kegiatan yang perna dilakukan hanya merupakan sosialisasi peraturan pengelolaan barang milik daerah. Namun secara mandiri sudah ada beberapa OPD yang mengikutkan bendahara pengurus barang mereka mengikuti bimbingan teknis yang diseenggarakan oleh penyelengara dari pihak swasta yang bekerjasama dengan narasumber dari BPKP (wawancara, 26 Agustus 2020)"

Menurut Manase Pongtasik, ST selaku Auditor Madya Inspektorat Kabupaten Toraja Utara mengatakan bahwa:

"Untuk Kabupaten Toraja Utara sangat jarang diadakan pelatihan tentang pengelolaan barang milik daerah, oleh sebab itu karena pentingnya penatausahaan barang milik daerah maka semua pengurus barang di setiap OPD perlu diberi pelatihan/diklat atau bimbingan teknis pengelolaan barang milik daerah untuk menambah pengetahuan mereka tentang penatausahaan barang mlik daerah yang lebih baik (wawancara, 26 Agustus 2020)".

Dari pernyataan tersebut, bahwa pada secara spesifik tentang pelatihan yang berkaitan dengan bagaimana penatausahaan barang milik daerah. kegiatan yang dilakukan selama ini lebih kepada kegiatan sosialisasi peraturan pengelolaan barang milik daerah. pelatihan tentang penatausahaan barang milik daerah merupakan suatu kegiatan yang sangat penting untuk dilakukan di wilayah Kabupaten Toraja Utara terutama kepada para pengurus barang milik daerah mengingat kegiataan ini belum pernah dilakukan sehingga seringkali penatuasahan barang milik daeraha khusus di DPKPP Kabupaten Toraja Utara sering terlambat dalam penyampaian laporan dan sering terjadi kesalahan dalam dalam laporan terkait barang milik daerah.

\section{PEMBAHASAN}

Proses pembukuan atau pencatatan yang dilakukan di kantor Dinas Perumahan Kawasan Permukiman Dan Pertanahan Kabupaten Toraja Utara masih menggunakan sistem manual dengan menggunakan aplikasi SIMDA barang. Dalam proses pencatatan BMD dilakukan setelah barang diterima dari pihak penyedia jasa barang yang dilengkapi dengan bukti dokumen yang lengkap. Barang milik daerah tersebut kemudian di input kedalam aplikasi SIMDA barang. Namun pencatatan barang milik daerah yang dilakukan oleh pengurus barang belum dilakukan dengan 
baik, dimana masih terdapat barang miliki daerah tidak tercatat dengan baik sehingga beberapa barang milik daerah tidak jelas keberadaannya karena masih belum baiknya proses pencatatan yang dilakukan oleh pengurus barang.

Pembukuan barang milik daerah merupakan kegiatan pendaftaran dan pencatatan barang milik daerah ke dalam daftar barang yang ada (SIMDA) pada pengguna barang dan pengelola barang. Maksud pembukuan barang milik daerah adalah agar semua barang milik daerah pada kantor Dinas Perumahan Kawasan Permukiman dan Pertanahan yang berada dalam penguasaan pengguna barang dan yang berada dalam pengelolaan pengelola barang tercatat dengan baik di dalam aplikasi SIMDA.

Belum terlaksananya pelaksanaan pembukuan atau pencatatan barang milik daerah pada Dinas Perumahan Kawasan Permukiman dan Pertanahan Kabupaten Toraja Utara tidak terlepas dari pengurus atau bendahara pengurus barang milik daerah tidak langsung melakukan pembukuaan atau pencatatan kedalam aplikasi SIMDA. Selain itu, belum adanya standar operasional prosedur yang dimiliki Dinas Perumahan Kawasan permukiman dan Pertanahan tentang pencatatan dan pembukuan barang milik daerah membuat pengurus barang belum melakukan pencatatan dan pembukuan dengan baik.

Pembukuan atau pencatatan barang milik daerah pada kantor Dinas Perumahan Kawasan Permukiman dan Pertanahan Kabupaten Toraja Utara disebabkan karena PPTK tidak segera menyerahkan dokumendokumen yang terkait dengan pengadaan barang sehingga menghambat pencatatan sehingga pengurus barang belum bisa melakukan pencatatan dan pembukuan dengan baik dan sehingga pencatatan barang sering terlambat dilakukan karena tidak lengkapnya data untuk diinput ke aplikasi SIMDA. Hal lain yang menyebabkan proses pembukuaan atau pencatatan belum dilakukan dengan baik karena dalam proses penginputan barang di aplikasi SIMDA harus dilakukan di kantor Badan Pengelolah Keuangan dan Aset Daeah selaku penyedia aplikasi dan hanya tersedia dua computer yang memiliki aplikasi SIMDA dan setiap bendahara pengurus barang harus bergantian dalam menggunakan aplikasi simda tersebut sehingga proses penginputa barang milik darerah menjadi terlambat karena terbatasnya ketersedian computer yang memiliki aplikasi SIMDA.

Dalam penatausahan barang milik 
daerah inventarisasi yang dilakukan di Dinas Perumahan Kawasan Permukiman Dan Pertanahan Kabupaten Toraja Utara belum dilakukan dengan baik. Hal ini bisa dilihat dari penatausahaan inventarisasi barang milik daerah dalam pembuatan atau pemberian label kode barang inventaris belum dilakukan dengan baik dimana tidak semua barang milik daerah memiliki label atau kode yang menggambarkan bahwa barang tersebut merupakan barang milik daerah yang digunakan oleh Dinas Perumahan Kawasan Permukiman Dan Pertanahan Kabupaten Toraja Utara sehingga memungkinkan barang yang tidak memiliki tanda berupa label atau kode yang tertera di barang tersebut bisa saja hilang. Selain itu, inventarisasi barang milik daerah dengan melakukan pembuatan rekap daftar barang disetiap ruang juga belum tersedia sama sekali. Sehingga data daftar barang di setiap ruang tidak jelas, begitu juga dalam hal kartu inventaris barang dalam ruangan juga belum ada sama sekali pernah dibuat, setiap ruangan yang ada di kantor Dinas Perumahan Kawasan Permukiman Dan Pertanahan Kabupaten Toraja Utara tidak memilik kartu inventaris ruangan.

Menurut Bafadal (2004) bahwa inventarisasi merupakan kegiatan pencatatan dan penyusunan daftar barang milik negara (BMN) yang secara tertib dan sistematis dilakukan sesuai dengan ketentuan atau pedoman yang berlaku

Untuk melakukan inventarisasi barang milik daerah maka tentu BMD tersebut harus di dilakukan pendataan dengan cara melakukan pembuatan label kode barang, melakukan pembuatan rekap daftar barang disetiap ruang, serta membuat kartu inventaris barang.

Menurut Khusna (2017) bahwa pemberian label kode barang bertujuan untuk mengamankan dan memberikan kejelasan barang milik negara. Selain itu, adanya daftar rekap barang di setiap ruangan akan memberikan kemudahan dalam melakukan pendataan atau pengecekan barang. Pembuatan kartu inventaris barang akan sangat membantu dalam melakukan pendataan barang milik negara terutama dalam melakukan monitoring kekayanaan negara baik itu berupah tanah, bangunan gedung, alat-alat dan sebagainya.

Selain inventarisasi, palaporan akan barang milik daerah merupakan aspek yang tidak boleh di abaikan. Oleh karena itu pelaporan yang dilakukan oleh pengurus barang milik daerah pada Dinas Perumahan Kawasan Permukiman Dan Pertanahan Kabupaten Toraja Utara belum sepenuhnya 
dilakukan dengan baik. Hal ini bisa dilihat dari masih seringnya laporan dari pengurus barang milik daerah yang sering terlambat dan sering kali mendapatkan teguran dari pihak Badan Pengelolah Keuangan dan Aset Daerah Kabupaten Toraja Utara akibat dari terlambatnya dalam melakukan penginputan dan pelaporan barang milik daerah. Tidak disiplinnya pengurus barang milik daerah dalam membuat laporan atas barang milik daerah. Proses pelaporan barang milik daerah yang dilakukan oleh pengurus barang semestinya melakukan koordinasikan dengan masing-massing bidang, dengan pimpinan dinas, inspektorat dan Kapala Bidang Aset pada Badan Pengelolah Keuangan dan Aset Daerah Kabupaten Toraja Utara agar dalam penyusunan laporan tidak terjadi kesalahan dalam penginputannya yang dapat mengakibatkan terjadinya ketidakakuratan data. Namum pada kenyataannya, pengurus barang sering kali tidak berkoordinasi dengan masing-masing kepala bidan sehingga sering kali data yang disajikan tidak sesuai dengan kondisi yang sebenarnya sehingga harus dilakukan perbaikan lagi agar laporan yang disajikan betul-betul akurat sesuai dengan fakta yang ada dilapangan.

Pelaporan barang milik daerah adalah adalah proses penyusunan laporan atas barang milik daerah yang dilakuakn setiap semester/tahun setelah proses inventarisasi atau pencatatan telah dilakukan (Kurnianto, 2017)

Pengurus barang milik daerah menyampaikan laporan atas pengguna barang baik secara semesteran dan tahunan kepada Kepala Daerah melalui pengelola dalam hal ini Badan Pengelolah Keuangan dan Aset Daerah Kabupaten Toraja Utara. Oleh karena, pengurus barang milik daerah dalam membuat laporan maka tentu harus menghimpun data (dokumen) dari seluruh pengguna barang milik daerah untuk kemudian dibuatkan laporan yang salah satunya mencakup jumlah barang maupun nilai serta dibuat rekapitulasinnya. Rekapitulasi tersebut digunakan sebagai bahan penyusunan neraca daerah.

Apek lain yang juga bisa membuat penatausahaan terlaksana dengan baik adalah tersedianya sumber daya manusia yang memadai, Sumber daya manuisa atau pengurus barang milik daerah pada Dinas Perumahan Kawasan Permukiman Dan Pertanahan Kabupaten Toraja Utara dalam hal jumlah sumber daya yang bertugas untuk melaksanakan penatausahaan barang milik daerah masih kurang memadai, saat ini petugas yang bertugas dalam 
melaksanakan penatausahaan barang milik daerah pada Dinas Perumahan Kawasan Permukiman Dan Pertanahan hanya satu orang dan tidak memiliki staf yang bisa membantunya dalam melaksanakan tugas penatausahaan barang milik daerah. selain itu, kemampuan petugas juga belum terlalu memadai dalam melakukan penatausahaan barang milik daerah, hal ini bisa dilihat dari sering terjadi keterlambatan dalam melakukan pembukuan barang milik daerah, tidak melakukan penginventarisasian dengan baik dengan memberikan label atai kode pada setiap barang, tidak tersedia daftar rekap inventaris barang dan seringnya terlambat dalam melakukan pelaporan. Ketidak mampuan dari petugas pengurus barang milik daerah pada DPKPP tidak terlepas karena belum pernahnya petugas mendapatkan pelatihan secara tekniks terkait dengan penatausahaan barang milik daerah sehingga pemahaman petugas masih kurang.

Petugas pengurus barang milik daerah yang hanya sendiri dalam mengurusi penatausahaan barang milik daerah pada instasinya tentu akan mengalami Kendal atau hambatan dalam penyelesaian tugasnya, mengingat petugas harus mengurusi barang milik daerah yang cukup banyak dan perlu ketelitian didalamnya. Oleh karena itu, perlu adanya penambahan jumlah petugas paling tidak ada staf yang ditunjuk untuk membantu dalam proses penatausahaan barang miliki daerah.

Petugas tidak pernahnya mendapatkan atau mengikuti kegiatan pelatihan atau diklat tentang penatausahaan barang milik daerah, sehingga membuat pengurus barang milik daerah di Toraja Utara tidak begitu mamahami apa yang harus dilakukan sehingga dalam proses penginputan data barang milik daerah di aplikasi SIMDA harus didampingi oleh pegawai atau petugas dari BPKAD. Oleh karena itu, perlu adanya pemberian pelatihan atau diklat kepada semua pengurus barang yang ada di Kabupaten Toraja Utara sehingga petugas memilik kemampuan untuk melakukan penatausahaan dengan baik.

\section{KESIMPULAN}

Berdasarkan hasil penelitian dan pembahasan dalam penelitian ini, maka dapat dapat disimpulakan bahwa penatausahaan BMD dalam hal pembukuan pada Dinas Perumahan Kawasan Permukiman Dan Pertanahan Kabupaten Toraja Utara masih bersifat manual dengan 
menggunakan sistem manual dengan menggunakan aplikasi SIMDA barang. Pembukuan oleh pengurus barang belum dilakukan dengan baik. Inventarisasi BMD belum dilakukan dengan baik, dimana pemberian label kode barang inventaris belum dilakukan, rekap daftar barang belum tersedia dan kartu inventaris barang dalam ruangan juga belum ada sama sekali pernah dibuat. Pelaporan BMD belum sepenuhnya dilakukan dengan baik, laporan dari pengurus barang masih sering terlambat akibat terlambatnya dalam melakukan penginputan sehingga pelaporan menjadi terlambat. Sumber daya manuisa pengurus BMD masih masih kurang memadai. selain itu, kemampuan petugas juga belum terlalu memadai dalam melakukan penatausahaan BMD disebabkan kerena tidak pernah mendapatkan pelatihan atau diklat terkait dengan penatausahaan barang milik daerah. untuk itu diharapkan pihak Dinas

\begin{abstract}
Perumahan Kawasan Permukiman Dan Pertanahan Kabupaten Toraja Utara memperbaiki pembukuan, melakukan pelabelan dan pemberian kode BMD serta membuat kartu inventaris barang dan melakukan penambahan jumlah petugas pengurus barang serta memberikan pelatihan terkait penatausahaan BMD kepada pengurus barang.
\end{abstract}

\section{REFERENSI}

Bafadal, Ibrahim. 2004. Manajemen Perlengkapan Sekolah. Jakarta: Bumi Aksara.

Khusna, Basariatul. 2017. Pelaksanaan Inventarisasi Barang Milik Kekayaan Negara di Kantor KPU Kabuputan Kulon Progo

Kurnianto, Okta Dwi. 2017. Pengaruh Penatausahaan BMD Terhadap Kualitas Laporan Keuangan Pemerintah Daerah (Studi Kasus Pada Pemerintah Kab. Magelang). Fakultas Ekonomi Dan Bisnis Universitas Hasanuddin 